Anglo-Saxon Studies 29

REPRESENTING BEASTS IN EARLY MEDIEVAL ENGLAND AND SCANDINAVIA 


\title{
Anglo-Saxon Studies
}

\author{
ISSN 1475-2468 \\ GENERAL EDITORS \\ John Hines \\ Catherine Cubitt
}

'Anglo-Saxon Studies' aims to provide a forum for the best scholarship on the Anglo-Saxon peoples in the period from the end of Roman Britain to the Norman Conquest, including comparative studies involving adjacent populations and periods; both new research and major re-assessments of central topics are welcomed.

Books in the series may be based in any one of the principal disciplines of archaeology, art history, history, language and literature, and inter- or multi-disciplinary studies are encouraged.

Proposals or enquiries may be sent directly to the editors or the publisher at the addresses given below; all submissions will receive prompt and informed consideration.

Professor John Hines, School of History, Archaeology and Religion, Cardiff University, John Percival Building, Colum Drive, Cardiff, Wales, CF10 3EU, UK

Professor Catherine Cubitt, Centre for Medieval Studies, University of York, The King's Manor, York, England, YO1 7EP, UK

Boydell \& Brewer, PO Box 9, Woodbridge, Suffolk, England, IP12 3DF, UK

Previously published volumes in the series are listed at the back of this book 


\title{
REPRESENTING BEASTS IN EARLY MEDIEVAL ENGLAND AND SCANDINAVIA
}

\author{
Edited by \\ Michael D. J. Bintley and Thomas J. T. Williams
}

THE BOYDELL PRESS 
All Rights Reserved. Except as permitted under current legislation no part of this work may be photocopied, stored in a retrieval system, published, performed in public, adapted, broadcast, transmitted, recorded or reproduced in any form or by any means, without the prior permission of the copyright owner

First published 2015

The Boydell Press, Woodbridge

ISBN 978-1-78327-008-8

Boydell Press is an imprint of Boydell \& Brewer Ltd

PO Box 9, Woodbridge, Suffolk IP12 3DF, UK and of Boydell \& Brewer Inc.

668 Mount Hope Ave, Rochester, NY 14620-2731, USA website: www.boydellandbrewer.com

A CIP catalogue record for this book is available from the British Library

The publisher has no responsibility for the continued existence or accuracy of URLs for external or third-party internet websites referred to in this book, and does not guarantee that any content on such websites is, or will remain, accurate or appropriate 


\section{Contents}

List of Figures and Tables vii

Acknowledgements $\quad x$

List of Contributors $\quad$ xi

List of Abbreviations xii

Introduction

Michael D. J. Bintley and Thomas J. T. Williams 1

1 Between Myth and Reality: Hunter and Prey in Early AngloSaxon Art

Noël Adams

2 '(Swinger of) the Serpent of Wounds': Swords and Snakes in the Viking Mind

Sue Brunning

3 Wreopenhilt ond wyrmfah: Confronting Serpents in Beowulf and Beyond

Victoria Symons

4 The Ravens on the Lejre Throne: Avian Identifiers, Odin at Home, Farm Ravens

Marijane Osborn

5 Beowulf's Blithe-Hearted Raven

Eric Lacey

6 Do Anglo-Saxons Dream of Exotic Sheep?

László Sándor Chardonnens

7 You Sexy Beast: The Pig in a Villa in Vandalic North Africa, and Boar-Cults in Old Germanic Heathendom Richard North

8 'For the Sake of Bravado in the Wilderness': Confronting the Bestial in Anglo-Saxon Warfare

Thomas J. T. Williams

9 Where the Wild Things Are in Old English Poetry

Michael D. J. Bintley 
10 Entomological Etymologies: Creepy-Crawlies in English Place-Names John Baker

11 Beasts, Birds and Other Creatures in Pre-Conquest Charters and Place-Names in England

Della Hooke

Index

283 


\section{Abbreviations}

ASD J. Bosworth and T. Toller, An Anglo-Saxon Dictionary (Oxford, 1898)

ASE Anglo-Saxon England

ASPR The Anglo-Saxon Poetic Records

ASSAH Anglo-Saxon Studies in Archaeology and History

BAR British Archaeological Reports

CDEPN The Cambridge Dictionary of English Place-Names, Based on the Collections of the English Place-Name Society, ed. Victor Watts (Cambridge, 2004)

CSASE Cambridge Studies in Anglo-Saxon England

DOE Dictionary of Old English: A to G Online, ed. Angus

Cameron, Ashley Crandell Amos, Antonette diPaolo Healey et al. (Toronto, 2007)

EETS Early English Text Society

es extra series

os original series

ss supplementary series

EPNS English Place-Name Society

ES English Studies

JEGP Journal of English and Germanic Philology

JEPNS Journal of the English Place-Name Society

LSE Leeds Studies in English

ME Middle English

MedArch Medieval Archaeology

NM Neuphilologische Mitteilungen

OE Old English

OED Oxford English Dictionary Online, accessed at http: / / www.oed.com/

OFr Old French

ON Old Norse

PDE Present Day English

PL Patrologia Latina 


\title{
6 \\ Do Anglo-Saxons Dream of Exotic Sheep?
}

\author{
László Sándor Chardonnens
}

In discussing the archaeological record, art, place-names, historiography and literature, the essays in this volume highlight the coexistence of people and animals in early medieval England. The Germanic tribes and few stray Celts who inhabited it lived in close proximity to a range of domestic and wild animals, the former category including cats and dogs, chickens and geese, horses and asses, cattle and pigs, sheep and goats, while the latter included fish, sea mammals, snakes, birds, deer, otters, badgers, rabbits, hares and all kinds of animal pests; particularly notable among the wild species were wolves, ravens and eagles - the three iconic beasts of battle commemorated in heroic poetry. Yet whereas most Anglo-Saxons would have been familiar with these nytenu and deora, including dragons (as the Anglo-Saxon Chronicle reminds us), it would be a stretch to assume that this familiarity extended to exotic animal species, such as camels, elephants, lions, phoenixes and scorpions. ${ }^{1}$ The Bible, the Physiologus, the Medicina de quadrupedibus and other non-Germanic sources testified to the existence of these animals in far-away corners of the world, and readers of the Wonders of the East would have encountered descriptions and depictions of fabulous beasts with eight legs, two heads and Valkyries' eyes, of lertices with asses' ears, sheep's wool and birds' feet, and many other ungefregelicu deor ('extraordinary beasts'). ${ }^{2}$ However, these written sources represented a world that was utterly different from Anglo-Saxon England, and they targeted highly educated audiences that were presumed to have been able to put these strange beasts into context.

Even though early medieval ideas about the natural world are far more integrative than modern attempts to categorise that world into discrete taxonomic ranks, there would seem to be a divide between the animal world that Anglo-Saxons could readily observe and the beasts that they knew only through religious and learned sources from the Mediterranean and the Near East. While indigenous creatures

${ }^{1}$ On dragons in the Anglo-Saxon Chronicle, see Symons, Chapter 3 in this volume.

${ }^{2}$ Andy Orchard, Pride and Prodigies: Studies in the Monsters of the Beowulf-Manuscript (Cambridge, 1995), p. 186. 
were domesticated, processed, hunted, avoided, feared or venerated, exotic animals were read about and marvelled at, and their absence from the Anglo-Saxon natural world led to their becoming the subject of metaphor and allegory. Animals, therefore, could be understood either as the output of God's creation, or as the input for symbolic thought.

A similar distinction can be discerned in early medieval techniques for foretelling the future. Taking dreams, natural phenomena, and significant moments in time as signs of future events, prognostication places that which has yet to happen on the same level of certainty as the present and the past. Whereas prognostication today is largely limited to weather forecasts, the Anglo-Saxons had a wide range of prognostic techniques at their disposal. These were inherited from the same Mediterranean and Near Eastern cultures that provided the basis for religion and learning; they first reached Continental monasteries in the late eighth century, and moved into Anglo-Saxon foundations in the ninth. ${ }^{3}$ Prognostication offered tools with which to interpret the future in all areas of life, from human concerns such as war and peace, life and death, health and illness, wealth and poverty, happiness and adversity, to noteworthy events in the natural world, including meteorology, agriculture and animal husbandry. This chapter examines the kinds of beasts that feature in prognostications from Anglo-Saxon England. Depending on the technique employed, prognostications may reveal the fate of animals as part of the output of a prediction, or their symbolic value as part of the input. The former tend to be closer to the Anglo-Saxon natural world than the latter, though some Anglo-Saxon scribes interfered with the homely animal

\footnotetext{
${ }^{3}$ For general studies of prognostication in Anglo-Saxon England, see Rolf. H. Bremmer and László S. Chardonnens, 'Old English Prognostics: Between the Moon and the Monstrous', in Monsters and the Monstrous in Medieval Northwest Europe, ed. Karin E. Olsen and Luuk A. J. R. Houwen (Leuven, 2001), pp. 153-66; László S. Chardonnens, Anglo-Saxon Prognostics, 900-1100: Study and Texts (Leiden, 2007); László S. Chardonnens, 'Context, Language, Date and Origin of Anglo-Saxon Prognostics', in Foundations of Learning: The Transfer of Encyclopaedic Knowledge in the Early Middle Ages, ed. Rolf H. Bremmer and Kees Dekker (Leuven, 2007), pp.317-40; László S. Chardonnens, 'Appropriating Prognostics in Late Anglo-Saxon England: A Preliminary Source Study', in Practice in Learning: The Transfer of Encyclopaedic Knowledge in the Early Middle Ages, ed. Rolf H. Bremmer and Kees Dekker (Leuven, 2010), pp. 203-55; László S. Chardonnens, 'Norm and Practice of Divination and Prognostication in Late Anglo-Saxon England', in Mantik, Schicksal und Freiheit im Mittelalter, ed. Loris Sturlese and Katrin Bauer (Cologne, 2011), pp. 51-64; Max Förster, 'Die Kleinliteratur des Aberglaubens im Altenglischen', Archiv für das Studium der neueren Sprachen und Literaturen 110 (1903), 346-58; Max Förster, 'Beitrage zur mittelalterlichen Volkskunde I-IX', Archiv für das Studium der neueren Sprachen und Literaturen 120 (1908), 43-52, 296-305; 121 (1908), 30-46; 125 (1910), 39-70; 127 (1911), 31-84; 128 (1912), 55-71, 285-308; 129 (1912), 16-49; 134 (1916), 264-93; Roy M. Liuzza, 'Anglo-Saxon Prognostics in Context: A Survey and Handlist of Manuscripts', ASE 30 (2001), 181-230; Roy M. Liuzza, Anglo-Saxon Prognostics: An Edition and Translation of Texts from London, British Library, MS Cotton Tiberius A. iii (Cambridge, 2011). Studies of specific prognostic techniques are referred to in the notes below.
} 
world displayed in prognostications in order to make the predictions seem more exotic.

That the fate of animals was sometimes not to be envied is poignantly demonstrated by the opening lines of the Old English De diebus malis:

Pa ealdan læcas gesettan on ledenbocun pæt on ælcum monðe beoð æfre twegen dagas pe syndan swyðe derigendlice ænigne drenc on to ðicgenne, oððe blod on to lætenne, forðan pe an tid is on ælcum pæra daga gif man ænige æddran geopenað on pære tide, pæt hit bið his lifleast, oððe langsum sar. Pæs cunnode sum læce, let his horse blod on pære tide, and hit læg sona dead. ${ }^{4}$

The doctors of old wrote in Latin books that there are always two days in each month on which it is very harmful to drink any [medicinal] potion or to let blood, because there is an hour in each of these days during which a vein that is opened will cause death or protracted pain. A certain physician tried this - bled his horse on such an hour - and it lay dead immediately.

This excerpt reports how a physician experimented (OE cunnode) on an animal, with lethal consequences, on one of the so-called Egyptian Days. These were the most feared of evil days in Late Antiquity and the Middle Ages, because it was thought that those who let blood or took medication on one of these days would almost certainly die. ${ }^{5}$ Various lists of Egyptian Days existed, recording three, twelve or twenty-four plihtlice dagas ('dangerous days'). ${ }^{6}$ In the type under discussion, two days were arbitrarily assigned to each month (e.g. 1 and 25 January, 4 and 26 February), which together make up the twenty-four Egyptian Days that survive in thousands of medieval manuscripts, particularly in liturgical calendars. As the De diebus malis demonstrates, animals

${ }^{4}$ London, British Library, MS Harley 3271, fols. 90v-91r; László S. Chardonnens, 'Ælfric and the Authorship of the Old English De diebus malis', in Limits to Learning: The Transfer of Encyclopaedic Knowledge in the Early Middle Ages, ed. Concetta Giliberto and Loredana Teresi (Leuven, 2013), pp.123-53 (p.127). All translations are mine unless noted otherwise.

${ }^{5}$ On Egyptian Days, see Chardonnens, Anglo-Saxon Prognostics, pp. 330-92; Chardonnens, 'Norm and Practice of Divination'; Chardonnens, 'Ælfric and the De diebus malis'; Max Förster, 'Die altenglischen Verzeichnisse von Glücks- und Unglückstagen', in Studies in English Philology: A Miscellany in Honor of Frederick Klaeber, ed. Kemp Malone and Martin B. Ruud (Minneapolis, 1929), pp. 258-77; Heinrich Henel, 'Altenglischer Mönchsaberglaube', Englische Studien 69 (1934-5), 329-49; Gundolf Keil, 'Die verworfenen Tage', Sudhoffs Archiv für Geschichte der Medizin und der Naturwissenschaften 41 (1957), 27-58; Jules Loiseleur, 'Les Jours égyptiens: Leurs variations dans les calendriers du moyen-âge', Mémoires de la Société nationale des antiquaires de France 33 (1872), 198-253; Robert Steele, 'Dies Aegyptiaci', Proceedings of the Royal Society of Medicine 12, Section of the History of Medicine, Supplement (1919), 108-21; Lynn Thorndike, A History of Magic and Experimental Science during the First Thirteen Centuries of our Era, 8 vols. (New York, 1923-58), vol. 1, pp. 685-8.

${ }^{6}$ London, British Library, MS Cotton Vitellius C. viii, fol. 22r-v (Chardonnens, AngloSaxon Prognostics, p. 342). 


\section{László Sándor Chardonnens}

suffered the same fate as humans if they were bled on an Egyptian Day. Though it might be considered cruel and unethical to subject an animal to an experiment whose deadly outcome is fixed in advance, the point to be considered here is that the physician decided to use a horse instead of (for instance) a camel. In fact, this reference to veterinary medicine ensured that this hapless horse was the only animal out of approximately 175 Anglo-Saxon prognostications to make it into Frederick Smith's Early History of Veterinary Literature and its British Development. ${ }^{7}$ What Smith did not know, however, is that the prognostications which appear in Anglo-Saxon manuscripts do not represent a native Germanic tradition, but reflect older, non-Germanic mantic practices. The reference to a horse, then, is pure chance; it might as well have been a camel, were it not for the fact that the medical experiment in the De diebus malis was an ad hoc addition by an Anglo-Saxon scribe. The Latin source on which the scribe based his translation reads: autenticorum in his medicorum cohibentur diuersorum potionum dictione, seu flebotomatum usus adibendi ('on these [days], they are deterred from [using] various potions or applying bloodletting, on the basis of the assertion of genuine doctors'), which is much more concise than the Old English, and leaves out the medical experiment altogether. ${ }^{8}$ Fortunately for Smith, in other words, the horse of the De diebus malis had an English pedigree to begin with, because it was introduced into the text by an early eleventh-century Anglo-Saxon scribe.

The same cannot be said for the majority of animals in Anglo-Saxon prognostications. Since most prognostications hail from Mesopotamia, Syria, Egypt, Greece and the Mediterranean, the animals mentioned tend to represent species indigenous to these areas. Some of these species, of course, were also native to Britain, or had become native by the time the Anglo-Saxons arrived, as a result of prior introduction by Celtic or Roman settlers. In such cases, references to these exotic animals could conveniently be retained because they had indigenous counterparts in Anglo-Saxon England. Early Continental texts on the twenty-four Egyptian Days, for instance, sometimes warned that cattle should not be broken on these days - an injunction that was retained in Anglo-Saxon manuscripts. ${ }^{9}$ Likewise, early Continental texts warn

\footnotetext{
${ }^{7}$ Frederick Smith, The Early History of Veterinary Literature and its British Development, 4 vols. (London, 1919-33), vol. 1, p. 70.

${ }^{8}$ MS Harley 3271, fol. 122r-v (Chardonnens, 'ÆElfric and the De diebus malis', p. 151).

${ }^{9}$ For early Continental versions, see Bern, Burgerbibliothek, MS 318 (facsimile via e-codices <http://www.e-codices.unifr.ch> [accessed 1 January 2015]); Karlsruhe, Badische Landesbibliothek, MS Aug. perg. 120, fols. 211v-212r (Wilhelm Schmitz, Beiträge zur lateinischen Sprach- und Literaturkunde (Leipzig, 1877), pp. 314-15; facsimile via Digitale Sammlungen <http: / / digital.blb-karlsruhe.de> [accessed 1 January 2015]); MS Aug. perg. 167, fol. 49r (Schmitz, Beiträge zur lateinischen Sprach- und Literaturkunde, pp. 313-14; facsimile via Digitale Sammlungen). For Anglo-Saxon examples, see London,
} 
that cattle should not be bled on the Egyptian Days, a stipulation adopted without any change by the Anglo-Saxons; compare the Latin, which notes that qui in istis tribus diebus hominem inciderit aut pecus, aut statim aut in die quarto morietur ('he who is bled on these three days, be it man or cattle, he will die immediately or on the fourth day'), with the Old English, which indicates similarly, se pe on pysum prim dagum his blod gewanige, sy hit man sy hit nyten, prs pe we secgan gehyrdan pxt sona on pam forman dxge oppe pam feorpan dxge his lif gexndad ('he who is bled on these three days, be it man or cattle, of him we have heard say that he will die immediately on the first day, or on the fourth day'). ${ }^{10}$ The animals that are affected by prognostications are mostly of the kind described here; that is, they had indigenous counterparts in Britain, ensuring a smooth transition from non-Germanic to AngloSaxon mantic practices.

The animals of the Revelatio Esdrae are a case in point. Ascribed to the prophet Esdras (Ezra), the Revelatio Esdrae is an annual prognostication that predicts meteorological conditions, yields in agricultural produce and animal husbandry, and human affairs, based on the weekday of either 1 January or Christmas Day. For instance: ${ }^{11}$

Gif middeswintres messedeg bið on sunnandeg, ponne bið god winter, and lengten windi, and drige sumer and wingeardas gode; and sceap beoð weaxende, and hunii beoð genihtsum and eal sib bið genyhtsummo. ${ }^{12}$

British Library, MS Cotton Caligula A. xv, fols. 129v-130r, and MS Cotton Tiberius C. vi, fol. 114r (both in Chardonnens, Anglo-Saxon Prognostics, p. 373).

${ }^{10}$ Paris, Bibliothèque nationale de France, MS lat. 12048, fol. 260v (facsimile via Gallica bibliothèque númerique <http://gallica.bnf.fr> [accessed 1 January 2015]), and London, British Library, MS Harley 585, fol. 190r-v (Chardonnens, Anglo-Saxon Prognostics, p. 342), respectively. For early Continental versions, see Karlsruhe MS Aug. perg. 167, fol. 49r; Paris, Bibliothèque nationale de France, MS lat. 2825, fols. 128v-129r (Ernest Wickersheimer, Les Manuscrits latins de médecine du haut moyen âge dans les bibliothèques de France (Paris, 1966), p. 59); MS nouv. acq. lat. 1616, fol. 12r (Wickersheimer, Les Manuscrits latins, p. 141); Reims, Bibliothèque Carnegie, MS 304, fol. 2r-v (facsimile via Gallica bibliothèque númerique).

${ }^{11}$ On the Revelatio Esdrae, see Marilina Cesario, 'Weather Prognostics in AngloSaxon England', ES 93 (2012), 391-426; Chardonnens, Anglo-Saxon Prognostics, pp. 491-500; Hardin Craig, The Works of John Metham, EETS os 132 (Oxford, 1916), pp. xxxii-xxxvii; Lorenzo DiTommaso, 'Pseudepigrapha Notes III: 4. Old Testament Pseudepigrapha in the Yale University Manuscript Collection', Journal for the Study of the Pseudepigrapha 20 (2010), 3-80 (pp. 16-33); David A. Fiensy, 'Revelation of Ezra (prior to Ninth Century A.D.): A New Translation and Introduction', in The Old Testament Pseudepigrapha I: Apocalyptic Literature and Testament, ed. James H. Charlesworth (Garden City, NY, 1983), pp. 601-4; Ria Jansen-Sieben, 'Middelnederlandse Jaarprognosen', Verslagen en mededelingen van de Koninklijke Academie voor Nederlandse Taal- en Letterkunde (1971), 210-66; Liuzza, Anglo-Saxon Prognostics, pp. 43-50; Edith A. Matter, 'The "Revelatio Esdrae" in Latin and English Traditions', Revue Bénédictine 92 (1982), 376-92.

12 Oxford, Bodleian Library, MS Hatton 115, fol. 149r-v (Chardonnens, Anglo-Saxon Prognostics, p. 496). On OE wingeard (Latin uindemia) as the fourth season, see Cesario, 'Weather Prognostics', p. 395. 


\section{László Sándor Chardonnens}

If Christmas Day is on a Sunday, winter will be good, spring windy, summer dry and the harvest season good; sheep will grow and there will be honey in abundance, and there will be peace and abundance on earth.

From their first appearance on the Continent in early ninth-century learned manuscripts, the prototypical news and weather reports in the Revelatio Esdrae proved hugely popular in monastic circles, and it did not take long for Anglo-Saxons to become acquainted with them. Though the predictions pertained to issues that were relevant to life on the Continent, the fact that the Anglo-Saxons had similar seasons, crops, animals and worries meant that they had plenty of common ground. One version of a Revelatio Esdrae from an Anglo-Saxon manuscript, for instance, makes the following predictions:

Si fuerit $\mathrm{k} \nmid$ ianuarius die dominico, hiems bona erit et suauis ac calida, uer uentuosus et sicca estas, uindemia bona; oues crescent, mel habundabit, senes morientur et pax fiet.

Si fuerit kł ianuarius die lunę, hiems mixta, uer bonus, estas uentuosa et tempestuosa, uindemia bona; ualitudo hominum, apes morientur.

Si fuerit kł ianuarius die martis, hiems nobilissima, uer uentuosus et pluuialis, estas bona; mulieres morientur, naues periclitantur in pelago; uindemia laboriosa.

Si fuerit kł ianuarius die mercurii, hiems dura et aspera, uer malus et estas bona, uindemia bona; frumentum bonum, iuuenes moriuntur, mel non erit, mercatores laborabunt.

Si fuerit kł ianuarius die iouis, hiems bona erit, uer uentuosus, estas bona; et habundantia erit, reges et principes peribunt, pax fiet.

$\mathrm{Si}$ fuerit kł ianuarius die ueneris, hiems stabilis et nix erit, uer bonus et estas dolor oculorum, uindemia bona; oues et apes peribunt, annona cara fiet.

Si fuerit kł ianuarius die saturni, hiems caliginosa, nix erit; annona cara erit, fructus habundabit, homines egrotabunt et ueterani moriuntur; uindemia bona. ${ }^{13}$

If 1 January is on a Sunday, winter will be good, mild but warm, spring windy and summer dry, the harvest season good; sheep will grow, honey will abound, old men will die and there will be peace.

If 1 January is on a Monday, winter will be mixed, spring good, summer windy and stormy, the harvest season good; there will be health among the people, bees will die.

If 1 January is on a Tuesday, winter will be most noble, spring windy and rainy, summer good; women will die, ships will be in danger on the sea; the harvest season will be toilsome.

${ }^{13}$ London, British Library, MS Cotton Tiberius A. iii, fol. 36r-v (Chardonnens, Anglo-Saxon Prognostics, pp. 496-7). 


\section{Do Anglo-Saxons Dream of Exotic Sheep?}

If 1 January is on a Wednesday, winter will be hard and difficult, spring evil, and summer good, the harvest season good; grain will be good, young people will die, there will be no honey, merchants will toil.

If 1 January is on a Thursday, winter will be good, spring windy, summer good; and there will be plenty, kings and princes will perish, there will be peace.

If 1 January is on a Friday, winter will be stable and there will be snow, spring will be good and summer too; there will be pain in the eyes, a good harvest season, sheep and bees will perish; resources will be dear.

If 1 January is on a Saturday, winter will be gloomy, there will be snow; resources will be dear, fruits will abound, people will fall ill and old people will die; the harvest season will be good.

The issues addressed in this text are not so outlandish that AngloSaxons would have had trouble relating to them, which is probably why the Anglo-Saxon text does not diverge significantly from the Continental version. A closely related Anglo-Saxon version predicts that sheep will multiply and honey will abound (Sunday); there will be no honey (Wednesday); sheep will die (Thursday and Saturday); and sheep's eyes will be weak (Friday). ${ }^{14}$

These two witnesses of the Revelatio Esdrae deal with sheep and bees exclusively, which Marilina Cesario explains by the fact that 'both were of great importance to Anglo-Saxon monastic and lay communities: sheep for the production of parchment, milk, cheese, and textiles, and bees for honey and wax'.${ }^{15}$ But while Cesario is right to point out that sheep and bees fulfilled important roles in AngloSaxon animal husbandry, which may account for the Revelatio Esdrae's being one of the most widespread prognostications in Anglo-Saxon England, the absence of other common farm animals (particularly cattle and pigs) is striking nonetheless. Indeed, the earliest Continental texts seem generally to limit themselves to sheep and bees, with cattle and pigs appearing only very infrequently. ${ }^{16}$ This might be due to

${ }^{14}$ MS Cotton Tiberius A. iii, fols. 41v-42r (Chardonnens, Anglo-Saxon Prognostics, pp. 494-5).

${ }^{15}$ Cesario, 'Weather Prognostics', p. 414.

${ }^{16}$ For early Revelatio Esdrae with sheep and bees, see, for instance, Leiden, Universiteitsbibliotheek, MS Voss. Lat. Q. 69, fol. 37v (Rolf H. Bremmer, 'Leiden, Vossianus Lat. Q. 69 (Part 2): Schoolbook or Proto-Encyclopaedic Miscellany?', in Practice in Learning: The Transfer of Encyclopaedic Knowledge in the Early Middle Ages, ed. Rolf H. Bremmer and Kees Dekker (Leuven, 2010), pp. 19-53 (p. 38)); Munich, Bayerische Staatsbibliothek, MS Clm 14456, fol. 75v (facsimile via Münchener Digitalisierungszentrum <http://www.digitale-sammlungen.de > [accessed 1 January 2015]); MS Clm 22053, fol. 21r-v (facsimile via Münchener Digitalisierungszentrum). For an early Revelatio Esdrae with pigs, cattle and bees, see Vatican City, Biblioteca Apostolica Vaticana, MS pal. lat. 1449, fols. 119v-120r (Giovanni Mercati, Note di letteratura Biblica e cristiana antica (Rome, 1901), pp. 77-9; facsimile via Manoscritti digitalizzati <http:// 


\section{László Sándor Chardonnens}

farming practices in the region of origin of this version of the Revelatio Esdrae. Though Continental scribes sometimes adapted the Revelatio Esdrae to local conditions, the Anglo-Saxons saw no need, apparently, to tailor the prognostication to their own specific needs once they were introduced to the sheep and bees variant. ${ }^{17}$

A possible exception is a Revelatio Esdrae uniquely attested in an English manuscript from the early post-Conquest period. 'An anomalous text which differs substantially' from other versions, this Revelatio Esdrae scales up the usual predictions by reporting more extreme weather conditions, bigger natural disasters, and greater suffering for humans and the natural world. ${ }^{18}$ As far as animals are concerned, the text predicts that: apes proficient, oues morientur ('bees will multiply, sheep will die', Sunday); quadrupedia plurima morientur ('most quadrupeds will die', Monday); piscatio multa ('much fishing', Wednesday); clades quadrupedum ('the destruction of quadrupeds', Thursday); monstruosa animalia nascentur, ... piscatio plurima ('monstrous animals will be born, ... fishing in plenty', Friday); and oues et porci morientur, mel multum, ... in mari belue et pisces morientur plurimi ('sheep and pigs will die, much honey, ... in the sea most beasts and fish will die', Saturday). ${ }^{19}$ Uniquely, this particular Revelatio Esdrae covers a much bigger slice of the animal world than any other version. It includes pigs alongside sheep and bees, and it subsumes large numbers of animal species under general labels, such as quadrupeds, fish and sea animals. The most interesting feature, however, is the unparalleled attention given to aquatic creatures, which suggests that this version was adapted to the needs of a maritime culture. Britain is an island, to borrow Bede's observation, so a Revelatio Esdrae reoriented along these lines must have proved helpful. Yet if this is indeed the case, it is a mystery why such a useful prognostication appears only in a single scientific manuscript from the inland abbey of Thorney - a location which can hardly have been conducive to its application in practice.

The example of the Revelatio Esdrae demonstrates that it was possible to tailor prognostications to local conditions, but that AngloSaxons did not often engage in noteworthy modifications. The sheep and bees from Continental sources were familiar sights in Britain, and Anglo-Saxons would therefore have known which creatures were

www.vatlib.it/home.php?pag=mss_digitalizzati> [accessed 1 January 2015]); for cattle and bees, see London, British Library, MS Harley 3017, fols. 63r-64v (Chardonnens, 'Appropriating Prognostics', pp. 253-4; facsimile via Digitised Manuscripts).

${ }^{17}$ See Cesario, 'Weather Prognostics', pp. 396-8.

${ }^{18}$ Ibid., p. 413.

${ }^{19}$ Oxford, St John's College, MS 17, fol. 149rb (Chardonnens, Anglo-Saxon Prognostics, pp. 499-500; facsimile via Faith Wallis, 'The Calendar and the Cloister', online at $<$ http:/ / digital.library.mcgill.ca/ms-17> [accessed 1 January 2015]). 
meant. Other kinds of prognostications, such as brontologies, probably underwent little modification for the same reason, though AngloSaxon brontologies do hold some intriguing surprises. 'Practised in the ancient world and continued into Christian culture as part of a larger interest in forecasting events by means of signs and portents', brontologies predict a range of human and natural affairs by means of the occurrence of thunder at various times or from various directions. ${ }^{20}$ Thunder was perceived as a destructive force, and most predictions have a negative outcome, particularly with regard to agriculture and animal husbandry. Se norð punor ('northern thunder'), for instance, becnað scepa deað, and cealfra and geogoðe ('signifies the death of sheep, calves and youth'). ${ }^{21}$ Similarly, gif on frigedxg gepunrad, ponne getacnað pxt nytena cwealm ('if it thunders on a Friday, it signifies the death of cattle' ${ }^{\prime 22}$ Around the time of the Norman Conquest, this prediction from a weekday brontology was redacted to specify that gif hit on frigedæig punrige, pæet tacnað sædeora cwealm ('if it thunders on a Friday, it signifies the death of sea animals'), again testifying to a late eleventh-century interest in maritime life, though early Continental texts indicate that $\mathrm{OE}$ nytena probably represents the original reading (e.g. peccora multa moritura esse ('cattle are to die')). ${ }^{23}$ The emphasis on farm animals is also evidenced in hour brontologies. If it thunders in the eighth hour, for instance, it signifies cwyld on heordum and fyperfetum ('destruction among herds and quadrupeds'). ${ }^{24}$ Month brontologies, on the other hand, address a wider array of animals, as the following text demonstrates:

Si tonitruum fuerit in mense ianuario multe conuentiones sunt: una de ouibus, alia de hominibus, .iii. de peccoribus, .iiii. de lignis, .v. de equis. Timendum est hoc tonitruum.

Si tonitruum fuerit in mense februario ad aurem pertinet uel ad alia, que referuntur in aliam, areas et semen pertenet.

$\mathrm{Si}$ tonitruum fuerit in mense martio timendum est, quia $\mathrm{ab}$ eo exspectatur mortalitas uel iudicium.

Si tonitruum erit in mense aprili semina periclitantur uel nabes.

${ }^{20}$ Roy M. Liuzza, 'What the Thunder Said: Anglo-Saxon Brontologies and the Problem of Sources', Review of English Studies ns 55.218 (2004), 1-23 (p. 7). On brontologies, see also Chardonnens, Anglo-Saxon Prognostics, pp. 247-69; Liuzza, Anglo-Saxon Prognostics, pp. 51-7.

${ }^{21}$ Cambridge, Corpus Christi College, MS 391, p. 714 (Chardonnens, Anglo-Saxon Prognostics, p. 269).

${ }_{22}$ MS CCCC 391, pp. 713-14 (Chardonnens, Anglo-Saxon Prognostics, pp. 260-1).

${ }^{23}$ Cologne, Erzbischöfliche Diözesan- und Dombibliothek, MS 102, fol. 52r-v (facsimile via Codices electroni ecclesiae Coloniensis <http://www.ceec.uni-koeln.de> [accessed 1 January 2015]); and MS Cotton Tiberius A. iii, fol. 40r-v (Chardonnens, Anglo-Saxon Prognostics, p. 261), respectively.

${ }^{24}$ MS Cotton Tiberius A. iii, fol. 37r-v (Chardonnens, Anglo-Saxon Prognostics, pp. 254-5). 


\section{László Sándor Chardonnens}

Si tonitruum fuerit in mense maio pluuie magne erunt, uel erba uel semina pululabunt.

Si tonitruum fuerit in mense iunio homines perecletantur uel ligna.

Si tonitruum fuerit in mense iulio pisces pericletantur.

Si tonitruum erit in mense agusto bilue uel reptilia perecletantur.

Si tonitruum erit in mense septembri uituli moriuntur.

Si tonitruum erit in mense octobri motantur aure.

Si tonitruum erit in mensis nouembri obes crescunt. ${ }^{25}$

If there is thunder in the month of January, there are many conventions: one of sheep, another of men, a third of cattle, a fourth of trees, a fifth of horses. This thunder is to be feared.

If there is thunder in the month of February, it pertains to the ears, or to something else, as is reported elsewhere; it pertains to threshing floors(?) and seeds.

If there is thunder in the month of March, it is to be feared, because mortality or judgement is to be expected from it.

If there is thunder in the month of April, seeds or ships are in danger.

If there is thunder in the month of May, there will be great showers, and weeds or seeds will sprout.

If there is thunder in the month of June, men or trees are in danger.

If there is thunder in the month of July, fish are in danger.

If there is thunder in the month of August, beasts (monsters?) or reptiles are in danger.

If there is thunder in the month of September, calves will die.

If there is thunder in the month of October, winds will blow.

If there is thunder in the month of November, sheep will grow.

This is the only Latin month brontology from Anglo-Saxon England a late tenth-century addition to the glossed Regius Psalter. The text reports on a number of natural, agricultural and human concerns, but it is nowhere more outspoken than in its predictions for the animal world. The sheep (January, November), cattle (January) and calves (September) already encountered in other brontologies are here joined by horses (January), fish (July) and beasts and reptiles (August). This mix of farm animals, fish and wild beasts is unique to this text - as we have already seen, other prognostications generally limit themselves to one of these groups of animals. Yet, as early Continental analogues corroborate (such as the pseudo-Bedan De tonitruis libellus ad Herefridum), an eclectic assortment of animals is a feature of month

\footnotetext{
${ }^{25}$ London, British Library, MS Royal 2. B. v., fol. 190r-v (Chardonnens, Anglo-Saxon Prognostics, p. 265)
} 
brontologies in general. ${ }^{26}$ The Latin month brontology from England is no exception, but the reference to reptiles is unattested elsewhere, and may be the fabrication of an Anglo-Saxon scribe who got carried away by the inauspicious topic of thunder. The same may be said of the readings in the only month brontology in Old English, which ignores animals altogether except for during the months of June and July:

On iunius monðe, hit bodeð mycele windes, and wulfene wodnysse and leona. On iulius monðe, hit bodeð wæstme wel gewænde and oref forfærð. ${ }^{27}$

In the month of June, it [thunder] signifies great storms, and madness among wolves and lions. In the month of July, it signifies crops doing well, and livestock will die.

The reference to oref ('livestock') in the prediction for July is not unusual, and wild beasts would not have been out of place either, as the Latin text shows. However, this vernacular text specifically singles out wolves and lions. By mentioning these beasts in one breath, the Old English month brontology bridges the gap between the natural world of Anglo-Saxon England and the exotic world of the Bible and the Wonders of the East. The scribe of this text, in other words, seems deliberately to have veered away from what might actually happen on English soil, towards symbolic ways of creating meaning by bringing in creatures from distant, exotic locations.

Similar motivations must have informed the work of the person who translated the sunshine prognostication into Old English. Sunshine prognostications are annual predictions that deliver mostly positive reports on human affairs, produce, and the finding of metals, depending upon which of the twelve days of Christmas is sunny. ${ }^{28}$ The English texts feature predictions that can be taken at face value, yet into which a prediction has been inserted that requires some learning before its meaning is understood:

${ }^{26}$ For the De tonitruis libellus ad Herefridum, see Cologne MS 102, fols. 49r-52v. See also PL 90, 609-14, and its appraisal in Charles W. Jones, Bedae Pseudepigrapha: Scientific Writings Falsely Attributed to Bede (Ithaca, NY, 1939), pp. 45-7. More manuscript copies of the De tonitruis have come to light since Jones's identification of Cologne MS 102; see Hilbert Chiu and David Juste, 'The De tonitruis Attributed to Bede: An Early Medieval Treatise on Divination by Thunder Translated from Irish', Traditio 68 (2013), 97-124.

${ }^{27}$ London, British Library, Cotton Vespasian D.xiv, fol. 103v (Chardonnens, Anglo-Saxon Prognostics, pp. 264-5).

${ }^{28}$ On sunshine prognostications, see Marilina Cesario, 'The Shining of the Sun in the Twelve Nights of Christmas', in Saints and Scholars: New Perspectives on Anglo-Saxon Literature and Culture in Honour of Hugh Magennis, ed. Stuart McWilliams (Cambridge, 2012), pp. 195-212; Chardonnens, Anglo-Saxon Prognostics, pp. 483-5. 


\section{László Sándor Chardonnens}

Py forma dæg drihtnes gebyrde gyf sunne scyneð, mycel gefea byoð mid mannum and genihtsum.

Gyf py æfteran dæg sunne scynep, ponne byð on ængelcynne gold eaðbegeate.

Gyf py pryddan dæg sunne scyneð, betweoh earmum mannum mycel gefeoht

byoð, and betweoh cynigum and rycum mannum micel sib.

Gyf py .iiii. dæge sunne scyneð, ponne pa olfenda mycel gold oðberað pan ætmettum pa pone goldhord healden scolden.

Gyf py .v. dege sunne scyneð, mycel blostman and bleoda beoð py gere.

Gyf .vi dæge sunne scyneð, driht sendeð mycele meolc.

Gyf .vii. dæge sunne scineð, mycele westmas on treowum beoð.

Gyf py .viii. dæge sunne scyneð, ðonne byð cwicseolfor eaðgeate.

Gyf pi .ix. dæge sunne scyneð, ponne god sendeð micelne fulluht on geare.

Gyf pi .x. dæge sunne scyneð, ponne byð se and ealle æa mid fixum ontined.

Gyf pi .xi dæge sunne scyneð, micel costung byð deaðes mid mannum.

Gyf pi .xii. dæge sunne scyneð, men beoð wace and byð micel sib on eorðan. ${ }^{29}$

If the sun shines on the first day of the Lord's birth, there will be much joy and abundance among the people.

If the sun shines on the second day, then gold will be easy to get among the English.

If the sun shines on the third day, there will be great strife among poor people, and great peace between kings and powerful men.

If the sun shines on the fourth day, then camels will carry away much gold from the ants that must guard the gold hoard.

If the sun shines on the fifth day, there will be many flowers and fruits in this year.

If the sun shines on the sixth day, the Lord will send much milk.

If the sun shines on the seventh day, there will be much produce on the trees.

If the sun shines on the eighth day, then quicksilver will be easy to get.

If the sun shines on the ninth day, then the Lord will send a great baptism in this year.

If the sun shines on the tenth day, then the sea and all rivers will be full of fish.

If the sun shines on the eleventh day, there will be great suffering of death among the people.

If the sun shines on the twelfth day, men will be weak and there will be great peace on earth.

${ }^{29}$ MS Hatton 115, fols. 149v-150r (Chardonnens, Anglo-Saxon Prognostics, p. 485). 
Most of these predictions can be readily understood, and those pertaining to animals mainly feature creatures already encountered in the Revelatio Esdrae and brontologies, that is, cattle (indirectly for day 6) and fish (day 10). But in relation to the discovery of metals, which is a central concern in sunshine prognostications, the prediction for day 4 mentions that 'camels will carry away much gold from the ants that must guard the gold hoard'. Chances were slim, however, that one could simply steal gold from gold-hoarding ants with the help of camels on English soil, because neither animal belonged to the Anglo-Saxon natural world. Rather, the reference is to a passage in the Wonders of the East that describes a curious custom:

Capi hatte seo ea in ðære ylcan stowe pe is haten Gorgoneus, pæt is Wælcyrginc. Pær beoð akende æmættan swa micle swa hundas. Hi habbað fet swylce græshoppan, hi syndon reades hiwes and blaces. Pa æmettan delfað gold up of eorðan fram foran nihte oð ða fiftan tid dæges. Đa menn ðe to ðam dyrstige beoð pæt hi pæt gold nimen, ponne lædað hi mid him olfenda myran mid hyra folan and stedan. Pa folan hi getigað ær hi ofer pa ea faran. Pæt gold hi gefætað on ða myran and hi sylfe onsittað and pa stedan pær forlætað. Đonne ða æmettan hi onfindað, and pa hwile ðe pa æmettan ymbe ða stedan abiscode beoð, ponne ða men mid pam myran and pam golde ofer ða ea farað. Hi beoð to pam swifte pæt ða men wenað pæt hi fleogende syn. ${ }^{30}$

The river is named Capi in the same place, which is called Gorgoneus, that is 'valkyrie-like'. Ants are born there as big as dogs, which have feet like grasshoppers, and they are red and black in colour. The ants dig up gold from the ground before night until the fifth hour of the day. People who are bold enough to take the gold bring with them male camels, and females with their young. They tie up the young before they cross the river. They load the gold onto the females, and mount them themselves, and leave the males there. Then the ants detect the males, and while the ants are occupied with the males, the men cross over the river with the females and the gold. They are so swift that one would think that they were flying.

This excerpt from the Wonders of the East introduces an ingenious method for stealing gold without having to delve for it: one simply diverts gold-hoarding ants with a free meal of male camels. Since the region described here is far removed from England, it seems unlikely that the prediction in the Old English sunshine prognostication could be taken literally. Sunshine prognostications from the Continent do not contain similar statements, which makes it plausible that the reference to the Wonders of the East was devised by an Anglo-Saxon scribe who perhaps wanted to recontextualise a prediction concerning

${ }^{30}$ Orchard, Pride and Prodigies, pp. 190-1. 


\section{László Sándor Chardonnens}

gold. ${ }^{31}$ Why the adaptor felt the need to do so is unclear, because less learned users of the sunshine prognostication are unlikely to have known what to make of this prediction. However, Cesario argues that, since 'wisdom literature appealed greatly to the Anglo-Saxons', the obscurity of the reference 'might have been part of the point, as the lack of explanation challenges the reader to determine the intended meaning'.$^{32}$ Cesario convincingly adduces a range of learned sources on camel-lore and myrmecology that were available to educated Anglo-Saxons, including a riddle by Aldhelm, Isidore of Seville's Etymologiae, Gregory the Great's Moralia in Iob, the Physiologus, and the Bible. In other words, the adaptor may have aimed to showcase the extent of his learning by adding a symbolic layer to the prediction the part of a prognostication that usually stayed within the bounds of the literal. At the level of output, after all, prognostications had to be as literal as possible, and if the point was to come up with predictions that were concrete enough to give a measure of certainty about the immediate future, then the prediction about the gold-hoarding ants did little to further that agenda, even if it did add an exotic touch.

Symbolism and associative logic were important strategies for creating meaningful patterns at the level of prognostic input. Thunder, for instance, was considered a destructive force, so its occurrence generally did not bode well; sunshine, by contrast, was a constructive force, so its occurrence was a good sign. This is why brontologies tend to predict misfortune whereas sunshine prognostications are auspicious. Thunder and sunshine as symbols of destruction and generation, therefore, condition the outcome of prognostications. A similar mechanism would seem to underlie the Revelatio Esdrae, where the day associated with the sun generally offers a positive prediction:

Si die .i. feria fuerint kł ianuarii, hiemps bona, et uer uentosum erit, aestas sicca et uindemia bona erit; boues crescent et mel abundanter erit, senes morientur et abundantia et pax erit. ${ }^{33}$

If 1 January is on a Sunday, winter will be good, spring windy, summer dry and the harvest season good; sheep will grow and there will be honey in abundance; old people will die and there will be abundance and peace.

Whereas the day associated with Saturn is viewed with greater ambivalence:

\footnotetext{
${ }^{31}$ See, for instance, Liège, Bibliothèque de 1'Université, MS 77, fol. 70r (Cesario, 'The Shining of the Sun', pp. 209-12).

${ }^{32}$ Marilina Cesario, 'Ant-Lore in Anglo-Saxon England', ASE 40 (2011), 273-91 (p. 283).

${ }^{33}$ London, British Library, MS Cotton Titus D. xxvi, fols. 10v-11v (Chardonnens, AngloSaxon Prognostics, pp. 497-8).
} 
Si .vii. feria fuerint kł ianuarii, hiemps turbolenta, uer uentosum; et fructus laboriosus erit, oues peribunt et senes morientur.

If 1 January is on a Saturday, winter will be stormy, spring windy; and harvest will be toilsome, sheep will perish and old people will die.

As far as animals are concerned, those at the output level of prognostications generally represent creatures known in the AngloSaxon natural world, such as farm animals and fish. Notable exceptions are the lions of the month brontology, and the camels and gold-hoarding ants of the sunshine prognostication, though it is likely that references to these creatures were included by learned scribes with a taste for the exotic. However, animals also feature at the input level of prognostication, where they seem to form an eclectic mix even by Anglo-Saxon standards.

Dream books (collections of dream topics, and their interpretations) are a safe haven for all imaginable concepts, things and creatures, no matter how trivial, controversial or exotic. It mattered little whether the subject of the dream was part of daily life, because the only limiting factor on what takes place in dreams is the human imagination. It was possible, for instance, to dream of having one's teeth fall out (indicating anxiety), of being made emperor (indicating honour), of sleeping with one's sister (harm), or of seeing a fierce elephant (accusation), though none of these events was likely to be included in prognostications. Instead, they were taken as signs of what the future held, which is borne out by the wording of dream book predictions; for instance, dracones uidere, dignitatem significat ('to see dragons signifies honour'). ${ }^{34}$ The dream books known in Anglo-Saxon England were structured on the alphabetical model attributed to the Old Testament prophet Daniel, which went back to Byzantine sources that in turn relied on pre-Byzantine Greek and Near Eastern oneiromantic traditions. ${ }^{35}$ As

\footnotetext{
${ }^{34}$ MS Cotton Tiberius A. iii, fols. 27v-32v (Chardonnens, Anglo-Saxon Prognostics, pp. 305-23).

35 Alphabetical dream books have been the subject of considerable study; for relevant sources in the present context, see Chardonnens, Anglo-Saxon Prognostics, pp. 290-329; László. S. Chardonnens, 'Dream Divination in Manuscripts and Early Printed Books: Patterns of Transmission, with a Comprehensive Hand List of Sources', in Aspects of Knowledge: Preserving and Reinventing Traditions of Learning in the Middle Ages, ed. Marilina Cesario and Hugh Magennis (Manchester, forthcoming); Lorenzo DiTommaso, The Book of Daniel and the Apocryphal Daniel Literature (Leiden, 2005), pp. 231-59, 378-402; Andreas Epe, Wissensliteratur im angelsächsischen England: Das Fachschrifttum der vergessenen artes mechanicae und artes magicae. Mit besonderer Berücksichtigung des Somniale Danielis (Münster, 1995); Steven R. Fischer, The Complete Medieval Dreambook: A Multilingual, Alphabetical Somnia Danielis Collation (Frankfurt am Main, 1982); Jutta Grub, Das lateinische Traumbuch im Codex Upsaliensis C 664 (9. Jh.): Eine frühmittelalterliche Fassung der lateinischen Somniale Danielis-Tradition (Frankfurt am Main, 1984); Liuzza, Anglo-Saxon Prognostics, pp. 38-43; Lawrence T. Martin, Somniale Danielis: An Edition of a Medieval Latin Dream Interpretation Handbook (Frankfurt am Main, 1981); Steven M. Oberhelman, Dreambooks in Byzantium: Six Oneirocritica in Translation, with Commentary
} 


\section{László Sándor Chardonnens}

Vilmos Voigt once posited, 'dreams reflect place and location', and in the case of the alphabetical dream books that reached Britain in the eleventh century, these texts were strongly coloured by their cultures of origin: one Anglo-Saxon dream book, for instance, includes dreams of eunuchs, emperors and Hercules. ${ }^{36}$ This exotic heritage is also apparent from the kinds of animals featured in Anglo-Saxon dream books, which include creatures known in the Anglo-Saxon natural world, such as farm animals, dogs and dragons, but also animals that never lived in England, yet that were nevertheless part of AngloSaxon intellectual and religious culture. The following provides an inventory of animals, animal products, and events involving animals from six Anglo-Saxon dream books:

\section{ANIMALS}

Ants: to see $\sim$ of any kind: great strife

Asses: to see $\sim$ : toil; to eat/to sit on (L (s)edere) $\sim$ : toil; $\sim$ braying or running free: strife with an enemy

Asses or kids: to see $\sim$ : wrongs in business

Bear: to be attacked by a $\sim$ : treachery of an enemy

Beasts: to be attacked by $\sim$ : to be overcome by enemies; to tame $\sim$ : esteem of enemies; running: disturbance; talking: serious trouble

Bees: to be attacked or injured by $\sim$ : one's life will be disturbed by men; to be stung by $\sim$ : one's mind will be troubled by foreign men; $\sim$ flying into one's house: abandonment/burning down of house; $~$ bearing honey: one will get money from prosperous people

Birds: to fight with $\sim$ : strife; to catch $\sim$ : profit; $\sim$ taking something: harm; in a nest: struggle in business; fighting among themselves: powerful people will fight among themselves; many : envy, contention and strife

Buck or goats: to see $\sim$ : advancement

Bull: to have a $\sim$, neither good not evil

Camels: to be attacked by $\sim$ : harm

Chicken: laying an egg: profit with worry; $\sim$ with chicks: increase in business; many $\sim$ : good

Dogs: $~$ barking or attacking: enemies seek to overpower one; greeting: guard against one's enemies; $\sim$ playing: thanks; $\sim$ running: much good; many $\sim$ : beware of enemies

Doves: to see $\sim$ : sadness

Dragons: to see $\sim$ : honour/good; $\sim$ flying overhead: treasure

and Introduction (Aldershot, 2008); Alf Önnerfors, 'Zur Überlieferungsgeschichte des sogenannten Somniale Danielis', Eranos 58 (1960), 142-58.

${ }^{36}$ Vilmos Voigt, 'How Dreams Reflect Place and Location? Georg von Gaal: Polylogikai Mulatság az Álomról és Alvásról (1821), Über den Schlaf (1823)', KOHT ja PAIK / PLACE and LOCATION: Studies in Environmental Aesthetics and Semiotics 5 (2006), 49-59 (p. 49). MS Cotton Tiberius A. iii, fols. $27 \mathrm{v}-32 \mathrm{v}$. 
Eagle: attacking: death/great joy; flying: death of one's wife; overhead: honour; many : evil hostility and treachery among the people

Elephant: to see a fierce $\sim$ : accusation

Fish: to see $\sim$ : rain; $\sim$ in the sea: great anxiety

Foal: to sit on a $\sim$ : deception in business

Frogs: to see $\sim$ : anxiety

Geese: many : good

Goat: to see a : hostile enemy close by; many : vanity

Horse: to sit on a white $\sim$ : good outcome/honour/good news; to sit on a black $\sim$ : anxiety / distress in the mind; to sit on a fallow $\sim$ : damage/ good; to sit on a bay $\sim$ : advancement; to sit on a chestnut $\sim$ : bad business / loss of one's goods; running free or being attacked by $\sim$ : harm

Lion: running: success in business; sleeping: bad business; to be attacked by a $\sim$ : rebellion among enemies

Mouse and lion: to see a $\sim$ : security

Ox: white or big : honour; hornless $\sim$ : one will overcome one's enemies; grazing: struggle in business; sleeping: evil in business; to sit on a white $\sim$ : honour

Pigs: to see $\sim$ : illness; many $\sim$ : misery

Quadrupeds: to see $\sim$ : anxiety; talking: enmity of a king

Serpent: to see a $\sim$ : enemies/malice of an evil woman; to be attacked by a $\sim$ : sight of an enemy; coming towards you: guard against evil women

Sheep: shorn : harm/not good; white $\sim$ : good

Stallions: many $\sim$ : destruction of one's goods

\section{ANIMAL PRODUCTS}

Butter: to eat $\sim$ : good news

Eggs: to have or eat $\sim$ : no effect

Honey: to eat $\sim$ : distress; to receive $\sim$ : be careful not to be deceived

Lard: to handle $\sim$ : a parent will die

Ivory: to handle $\sim$ : hindrance; to buy or sell $\sim$ : great sadness

Silk or fine cloth: to have $\sim$ : sometimes good and sometimes evil

\section{EVENTS INVOLVING ANIMALS}

Claws: to see $\sim$ : anguish

Fish pond: to wash in a $\sim$ : joy; to fall into a $\sim$ : happiness

Hunt: to $\sim$ : wealth/profit/guard against enemies

Plough: to $\sim$ : wealth ${ }^{37}$

${ }^{37}$ London, British Library, MS Sloane 475, fols. 217v-218r; MS Cotton Tiberius A. iii, fols. 27v-32v, 38r-39v, 42r-v; MS Cotton Titus D. xxvi, fols. 11v-16r; and MS Hatton 115, fols. 


\section{László Sándor Chardonnens}

The dream topics and their interpretations provide insight into how alphabetical dream books create meaning through associative logic. Animals with negative connotations, for instance, are associated with misfortune, such as the association between serpents and evil women, which is probably based on Scripture. Animals with positive connotations, such as lions, are good signs, except when they turn against the dreamer. Some types of animals (beasts, for instance) stand for human attributes or fellow human beings, and the nature of their interaction with the dreamer dictates the meaning of the dream. Some dreams, on the other hand, create meaning through opposing values, as in the dream of a dove boding sadness. Since most animals and events involving animals would have been familiar to the AngloSaxons from daily life or religion and learning, their meaning would have made sense to the audience. That said, the animals portrayed in alphabetical dream books are not native species, strictly speaking, although some might, of course, have existed in Anglo-Saxon England nonetheless. The exceptions (camels, elephants and lions) are a reminder that the roots of alphabetical dream books did not lie in northwest Europe. The Anglo-Saxons would have known these animals, though, since they made an appearance in religious and learned sources, such as the Wonders of the East (where camels are even depicted in the section on the gold-hoarding ants), while the dream of the mouse and the lion was probably inspired by Aesop's fable. As far as exotic animal products are concerned, Anglo-Saxons were familiar with ivory, albeit not always from elephants' tusks, and silk would have been a precious import product. Anglo-Saxons would have had no problems, then, in adopting a non-Germanic form of dream divination, because there was sufficient overlap between their own natural world and that of the Mediterranean and Near East.

Rather than speculate on how far the knowledge of exotic animals extended in Anglo-Saxon England, it is perhaps more interesting to note that the dream books are heavily oriented towards the Mediterranean and the Near East. Asses, for instance, are a stock feature of alphabetical dream books, probably due to their intensive use in the region of origin. Their role in Anglo-Saxon England, however, was minor. Pigs, on the other hand, were important in Anglo-Saxon England, but have strongly negative associations in dream books which probably stem from the earliest Mediterranean oneirocritic sources. Some animals, moreover, are wholly absent from Anglo-Saxon dream books, even though it would have been relatively easy to expand the store of dream images. The Anglo-Saxons would

150v-152v (Chardonnens, Anglo-Saxon Prognostics, pp. 297-329). 
have understood the simple rules of associative logic underlying the way that meaning is created in dream books, but they did not act on this knowledge. So there are dogs but no cats, and some animals of cultural significance to Anglo-Saxons are completely absent, such as badgers, deer, ravens and wolves. As we have already seen from other prognostic techniques known from Anglo-Saxon sources, it would appear that the Anglo-Saxon scribes who copied alphabetical dream books were content to make do with the predictions handed down through the ages - and they were not alone in this. Badgers and deer, for instance, never made it into alphabetical dream books in the medieval period, while cats and ravens first appeared in early printed dream books from Italy and Germany in the $1470 \mathrm{~s} .{ }^{38}$ Wolves, finally, surface in a thirteenth-century French dream book, but occupy a marginal position. ${ }^{39}$

In conclusion, the natural world that Anglo-Saxons encountered in prognostications resembled the one in which they lived, even if the world in which these prognostications had originated could not be mapped fully onto Anglo-Saxon England. The animals whose fate was predicted in prognostications tend to represent species also known in Britain, such as cattle and bees. This made it easy for Anglo-Saxons to adopt these prognostications without having to undertake major revisions. The animals that formed the input of predictions, however, tend to be more exotic, such as the camels, elephants and lions of alphabetical dream books. Since the Anglo-Saxons were familiar with religious and learned sources that featured these same animals, it was possible for them to grasp their symbolic significance. What is puzzling, though, is that the opportunity to add an indigenous touch to alphabetical dream books was not embraced, though other AngloSaxon scribes deliberately complicated prognostications by revising predictions or including references to exotic animals like lions, camels and gold-hoarding ants. It is possible that by diminishing the prophetic potential of predictions in brontologies and sunshine prognostications, scribes removed these techniques from the sphere of divination and drew them into a tradition of learning. Certainly, there are few signs that such prognostications ever fully realised their mantic potential, since the manuscripts in which they were transmitted were firmly situated within a monastic culture of learning. By contrast, other types of prognostications, such as alphabetical dream books, displayed an animal world that was manifestly more exotic, and that would actually

${ }^{38}$ For a dream about cats, see Ego sum Daniel propheta [...] ([Trent: Albrecht Kunne, c. 1475]; GW 7905); for dreams about ravens, see Interpretationes seu somnia Danielis prophete ([Rome: Johannes Bulle, c. 1478/9], GW 7920).

${ }^{39}$ See Paris, Bibliothèque nationale de France, MS fr. 1553, fols. 285v-286v (Walther Suchier, 'Altfranzösische Traumbücher', Zeitschrift für französische Sprache und Literatur 67 (1957), 129-67 (pp. 141-6); facsimile via Gallica bibliothèque númerique). 
have benefited from some domestication and the inclusion of species more familiar from the English landscape. Needless to say, this never happened, which suggests that if Anglo-Saxons ever dreamt of sheep, it would have been of exotic sheep. 